\title{
NEW REQUIREMENTS FOR STATUTORY AUDITORS IN EUROPEAN UNION
}

\author{
Botez Daniel \\ "Vasile Alecsandri” University of Bacău \\ daniel63331@yahoo.com
}

\begin{abstract}
Statutory audit missions are completed through the drawing up of audit reports. The elements of an audit report are standardized by International Standard on Audit ISA 700 "Forming an opinion and reporting on financial statements”. In April 2014, Directive 2006/43/EC on statutory audits of annual accounts and consolidated financial statements has been amended by Directive 2014/56/EU of the European Parliament and of the Council of April 2014. All in the month of April 2014, the European Parliament and the Council adopted Regulation No 136/66/EEC. 537/2014 Regarding specific requirements relating to statutory audits of public interest entities. These documents provide for expanded content for the report of the Audit Board and some additional requirements. In this way the Directive 2014/56/EC lays down mandatory items in the report of the Audit Board additional to those laid down by international reference. Regulation lays down the duty of auditor's entities of public interest to include in the report of the Audit Board items additional to those laid down by the Directive. Furthermore, lays down an obligation for them to send, in addition to the report of the Audit Board, Other reports content well specified: a supplementary report addressed to the audit committee of the entity audited; a report to the supervisory authority of the entity of public interest; a report of transparency, which will be published on their web site; and, A report by the authority to the monitoring by reporting list of entities of public interest audited and of revenue. Such reports together with some comments, is the subject of article.
\end{abstract}

\section{Keywords}

statutory audit; audit report; public interest entities

\section{JEL Classification}

M42

\section{Introduction}

Statutory audit mission carried out by external auditors shall be completed by the drawing up of the audit report. This is the document by which the auditors shall transmit to financial statements users their opinion with regard to the degree to which they show a true and fair view of financial position and financial performance, together with the other information presented.

Requirements for the components of the required audit report and the manner of expression of opinion shall be provided by the International Standard on Audit ISA 700 "Forming an Opinion and Reporting on Financial Statements". For situations in which shall be issued opinions changed and shall be included and other information in the report the auditor also have to appeal to the International Audit Standards ISA 705 "Modifications to the Opinion in The Independent Auditor's Report" and ISA 706 "Emphasis of Matter Paragraphs and Other Matter Paragraphs in The Independent Auditor's Report”.

In accordance with these requirements, the components of the audit report shall be the following:

1. Title - auditor's report must have a title that clearly indicates that it is a report 
of an independent auditor;

2. The consignee - auditor's report must be sent as circumstances provide for mission;

3. The introductory paragraph - the introductory paragraph of auditor's report must:

- identify the entity whose financial statements have been audited;

- state that financial statements have been audited;

- identify title of each situations which make up their accounts;

- make reference to the significant accounting policies and other explanatory information; and

- specify the date or the period covered by each financial situation which make up their accounts.

4. Management Responsibility for financial statements - this section of auditor's report describes responsibilities those persons in the organization who are responsible for the preparation of the financial statements. Description must include an explanation for the fact that the management should be responsible for the preparation of the financial statements, in accordance with the general financial reporting applicable, and for that internal control which they calculate necessary to allow drawing up the financial statements free of significant misstatement, caused either by fraud or error.

5. Auditor's responsibility - auditor's report must specify that auditor's responsibility is to express an opinion on financial statements following the audit, must specify that the audit has been carried out in accordance with International Auditing Standards and that those standards shall provide that the auditor also to comply with ethical requirements and that the auditor plan and carry out audits in such a way as to obtain a reasonable assurance of the extent to which financial statements are free of significant misstatement .

Describe a sufficient audit trail specifying aspects:

- An audit involves performing procedures to obtain audit evidence relating to the values and presentations of the financial statements;

- Selected procedures will depend on the auditor's judgment, Including with the assessment of the risk that financial accounts to submit significant distortions caused either by fraud or error. In assessing those assessments to the risk, the auditor shall take into account relevant internal control for the drawing up and presentation of the financial statements accurate for entity, with a view to the preparation of audit procedures appropriate circumstances, but without the purpose of expressing an opinion on internal control effectiveness.

- An audit should also include assessment of the degree of appropriateness of accounting policies used and reasonable nature of accounting estimates made by management, as well as and the overall presentation of the financial statements.

6. Auditor's opinion - when express an opinion unchanged with respect to the financial statements drawn up in accordance with a general framework of fair presentation, auditor's opinion should be, except where the laws or regulations provide otherwise, use one of the following phrases, which shall be considered to be equivalent:

- Statements are true, from all points of view significant, ... in accordance with (general framework of financial reporting applicable); or

- Financial statements gives a correct and accurate ....... In accordance with (general framework of financial reporting applicable). 
7. Other responsibilities for reporting - these other responsibilities for reporting should be dealt with in a separate section of auditor's report whose subtitle will be "Report on other laws and regulations" or another subtitle content appropriate section.

8. Auditor's signature - auditor's report must be signed.

9. Date of report auditor - auditor's report must be dated no earlier than the date on which the auditor has obtained sufficient appropriate audit evidence on which to base the auditor's opinion on the accounts, including samples according to which:

- have been drawn up all situations included in the financial statements, including the notes relating thereto; and

- the persons with the authority recognized have declared that they have assumed responsibility for those financial statements.

10. Address auditor - auditor's report must specify the location within the jurisdiction in which the auditor carries out its activities.

\section{Additional requirements for the audit report}

In April 2014, Directive 2006/43/EC on statutory audits of annual accounts and consolidated financial statements has been amended by Directive 2014/56/EU of the European Parliament and of the Council of April 2014. In the text meet its provisions relating to the audit report. Article 28, "Establishment of the audit report" are referred to as required to be submitted elements of entity relating to the identification, date and period covered by financial accounts, find the frame of financial reporting, describe the scope of the audit with the indication standards applied and the opinion.

In addition, Directive makes a few important entries:

- Inclusion in the audit report an opinion and a statement provided for by the European directive on the annual accounts, which refers to the auditor's obligation to deliver an opinion on:

$\square$ report consistency managers to financial accounts for the same financial year; and

$\square$ preparing the report administrators in accordance with legal requirements applicable and

$\square$ of a declaration if,based on the knowledge and understanding acquired in the audit with regard to the enterprise and its environment, have identified significant erroneous information presented in Manager's report, indicating nature of these erroneous information;

- Provides a statement of any uncertainty associated significant events or conditions which may significantly to doubt the ability of the entity to continue to carry on their activities;

- Make explanations about the situation in which statutory audits has been carried out by several auditors (more firms of auditors).

\section{Requirements for the audit of entities of public interest}

At all in the month of April 2014, the European Parliament and the Council adopted Regulation (EC) No 537/2014 concerning specific requirements relating to statutory audits of public interest entities.

By entities of public interest shall mean, in national law: "credit institutions; non-bank financial institutions, as defined in accordance with the rules of law, entered in the Register general; payment institutions and institutions issuing electronic currency, which are defined according to the law, Credit relating to the services of payment and whose activity is limited to the provision of the services of payment, i.e. issue of the currency and to the provision of electronic payment services; insurance companies, 
insurance-reinsurance and reinsurance; entities authorized, covered and monitored by the Commission for monitoring of private pension Systems; companies financial investment services, management companies investment, collective investment undertakings, Central repository, the houses of compensation and operators in the market/ system authorized/ prompted the National Securities Commission; commercial companies whose securities are admitted to trading on a regulated market; companies/ national companies; Companies wholly or major state; autonomous state; legal persons who belong to a group of companies and shall enter into the perimeter of consolidation of a parent undertaking established in Romania, which has an obligation to apply International Financial Reporting Standard, in accordance with the legal provisions in force; organizations without purpose bears patrimonial liability receiving financing from public funds”.

Only for auditing them, the new European Regulation lays down some requirements that opposed framework set out by the International Standard on Auditing audit report. Thus, the auditors of entities of public interest must be present in the context of the report following their aspects:

- Indicates person or body which has appointed statutory auditors or audit firms. Usually, statutory auditors shall be appointed by the general meeting of shareholders;

- Indicate the date of appointment and the period of mission continues, including any renewals of statutory auditors or audit firms. It is a piece of information required in order to ascertain compliance with the requirements concerning the rotation of auditors a mission of auditors to a public entity. Regulation lays down that no initial mission to a statutory auditor or firm of auditors and this combined with any further extension may not exceed a maximum period of ten years, but there are also some of the exceptions.

- Provides, in support of the audit opinion, the following:

$\square$ a description of the most important risks of declarations, including the risks of significant inaccuracy evaluated assigned to fraud;

$\square$ a summary of auditor measures in response to these risks; and

where appropriate,critical remarks on the edge those risks;

- Explains to what extent statutory audits was considered able to detect irregularities, including fraud;

- Confirms that the opinion is in accordance with the report in addition to the audit committee;

- Declares that he services which are not prohibited (Regulation determines what services are prohibited), and that statutory auditors or audit firms have remained independent from the entity audited during audit;

- Indicate any services, in addition to statutory audits, which have been provided by statutory auditor or firm of auditors or by any member of the network of which it is part statutory auditor or audit company, for the benefit of entity audited, mother of his undertaking or enterprise controlled by this and which have not been communicated in the report of the administrative, or in financial statements.

Furthermore, the Regulation lays down that Member States may lay down additional requirements as regards the content of the audit report.

In addition to the audit report referred to above, the auditors of entities of public interest must draw up and submit an additional report to the audit committee of the entity audited not later than the date of submission of the audit report.

The report explains the results additional statutory audits carried out and to achieve at least the following:

- Include a declaration of independence by confirming in writing, on a yearly basis, that statutory auditor, audit company and partners, executives and managers carrying out statutory audits are independent of the audited entity; 
- If the audit has been carried out by a firm of auditors, the report identifies each key audit partner which has been involved in audits;

- Describe the nature, frequency and extent of such communication with the audit committee or with the body with equivalent function of the audited entity, the body of the management and the administration or supervision of the entity audited, including the data meetings held with these bodies;

- Includes a description of the scope and timetable audit;

- In the case in which they have been appointed several auditors or firms of auditors, distribution of tasks between statutory auditors and/or firms of auditors;

- Describes the methodology used, including balance sheet liability categories which have been checked directly with the categories whose operational has been based on testing systemic and compliance, including an explanation of substantial fluctuations of weighting is tested by the fund and of conformity as compared with previous year, even if statutory audits of that year has been carried out by auditors other statutory or other firms of auditors;

- Communicate the level of materiality applied to carrying out the statutory audits of financial statements as a whole and, as the case may be, the materiality for certain categories of transactions, balances accounting or disclosed, and shall inform of the qualitative factors which have been taken into account in determining the materiality;

- Reports and explains reasoning related to events or conditions identified in the course audit which may create serious doubts regarding the ability of the entity toand continue to carry on their activities and if these events or conditions constitute substantial uncertainty and provides a summary of all the guarantees and letters of comfort, commitments of public intervention and other support measures which were taken into consideration to assess the potential to continue such activities;

- Report on any significant deficiencies in the financial statements for entity audited or, in the case consolidated financial statements, of the system of internal financial control of parent company and/or the accounting system. For each deficiency significant additional report indicates whether deficiency in question has, or has not been resolved by management;

- Report on any important problems involving failure to comply with the actual or presumed acts in law and administrative acts or of the statutes which have been identified in the course auditing, To the extent that they are considered to be relevant to enable the audit committee to carry out their tasks;

- Reports and analyzes the valuation methods applied to the various items in the financial statements or consolidated annual, including any impact of the change of such methods;

- In the case of a statutory audit of consolidated financial statements, explain the scope of consolidation and the exclusion criteria applied by the entity audited unconsolidated entities, if any, as well as if the criteria applied are in accordance with the financial reporting framework;

- Reports:

$\square$ any considerable difficulties, if any, encountered during audit;

$\square$ important matters, if any, arising out of statutory audits and which have been discussed or which have been the subject correspondence with the management; and

$\square$ other aspects, if any, arising out of statutory audits and which, in the opinion of professional auditor, are significant for the supervision of the financial reporting process.

Member States may lay down additional requirements as regards the content of the report in addition to the audit committee. At the request of a statutory auditor of a firm of auditors, statutory auditors or audit firms main was discussing the problems arising out of statutory audits, referred to in the report in addition to the audit 
committee the audit committee, with the administration or, as the case may be, the supervisory body of the entity audited.

Additional audit report addressed to the audit committee shall be signed and shall be dated.

A significant size has and the report to the auditor also require the supervisory authority of the entity of public interest (at the national level, The Financial Supervisory Authority), as well as in certain cases, the supervisory authority of statutory audit work (at the national level, Supervisory Board in the Public Interest of the Accounting Profession).

The report shall be drawn up for the reporting of circumstances about which auditors has knowledge in the course of the mission audit relating to:

- A significant violation of the acts in law and administrative acts which provide, as the case may be, conditions for the approval or which specifically govern the conduct of its business activities in the public interest entity;

- A threat or a doubt with respect to significant continuity officials said entity of public interest;

- Impossibility to issue an audit opinion with respect to the financial statements or issue of an opposing opinion or an opinion with reservations. Also, statutory auditors or audit firms have a duty to report any information referred to above which has come to their knowledge in the course of carrying out statutory audits of the undertakings in close connection with the entity of public interest in performing, also statutory audits.

Member States may require from the auditor or firm of auditors additional information, provided that they are necessary for effective supervision of financial market, such as national law. Regulation provides for and the establishment of a dialog between the auditors of credit institutions and insurance undertakings and the supervisory authorities.

Within four months of the end of each financial year, statutory auditor or firm of auditors who carry out statutory audit or audits of entities operating in the public interest shall publish an annual report of transparency. Annual Report of transparency shall be published on the site dedicated to the statutory auditor or firm of auditors and remains available on site for at least five years from the date of its publication on the site.

Annual Report of transparency shall include at least the following elements:

- A description of the structure of legal entities and for the owners of firms of auditors;

- If statutory auditor or firm of auditors is part of a network:

$\checkmark$ description of the network and of the organization of the legal and structural;

$\checkmark$ name of each statutory auditor serving in independent operation or each firm of auditors which form part of the network;

- A description of the structure of a governess of the firm of auditors;

- A description of the system of internal control of the required quality of statutory auditor or firm of auditors and a statement of the organism administrative or management about the efficiency of its operation should be established; • That had the most recent operational for quality assurance;

- A list with the entities of public interest for which statutory auditor or firm of auditor's statutory audits to be carried out in the course of a financial year preceding;

- A declaration concerning the practices implemented by statutory auditor or firm of auditors in matters of independence, which also confirm that was carried out an assessment of the compliance with internal independence;

- A statement concerning statutory auditor policy or firm of auditors as regards training of statutory auditors;

- Information on basis of remuneration of the partners in firms of auditors; 
- A description of policy statutory auditor or firm of auditors in relation to rotation of partners- key and staff, and

- Where are not published in his financial situation, information on the total turnover of statutory auditor or firm of auditors, broken down on the following components:

$\checkmark$ revenue arising from statutory audits of annual accounts and consolidated accounts of entities operating in the public interest and of entities belonging to a group of undertakings whose undertaking- mother is an entity of public interest;

$\checkmark$ revenue arising from statutory audits of annual accounts and consolidated accounts of other entities;

$\checkmark$ income deriving from services allowed which are not of the Audit Board, rendered by entities which are audited by statutory auditor or firm of auditors; and

$\checkmark$ income arising from services that are not of the Audit Board, rendered other entities.

The report of the transparency shall be signed by statutory auditor or by the firm of auditors.

Statutory auditor or firm of auditors shall provide annually its competent authority a list of entities operating in the public interest audited, according to the revenue collected from them, present such income as follows:

- Income from statutory audit;

- Revenues from services other than those prohibited, provided for by Community law and national law; and

- Revenues from services other than those prohibited, which are not provided for by Community law and national law.

\section{Conclusions}

New requierments requierd for auditing entities of public interest increase audit companies responsibility toward their clients, entities of public interest, but also toward the supervisory body of the capital market, the supervisory bod of the accounting profession, but also toward their own professional body.

This situation will make changes in the policies of management of the audit companies, promoting increased rigor of the method of collection and reporting of data, associated with better positioning of these companies of the market of professional services.

\section{References}

Accounting Law No 82/1991, with subsequent amendments and additions.

Directive 2014/56/EU of the European Parliament and of the Council of 16 April 2014 amending Directive 2006/43/EC on statutory audits of annual accounts and consolidated financial statements.

ISA 700 "Forming an Opinion and Reporting on Financial Statements", in IAASB Handbook of International Regulations for Quality Control, Auditing, Review, Other Assurance Services and Related Services, Edition 2012, vol. I, translated and reissued the CAFR, Bucharest, 2013.

Regulation (EU) no. 537/2014 of the European Parliament and of the Council of 16 April 2014 concerning specific requirements relating to statutory audits of public interest entities. 